\title{
A case report of bilateral choroidal metastases of epithelial carcinoma of pancreas
}

\author{
Um relato de caso de metástases de coroide bilaterais de carcinoma epitelial de pâncreas
}

\author{
Ahmet Burak Bilgin ${ }^{1}$, Kadri Cemil Apaydin ${ }^{1}$, Mustafa Unal ${ }^{1}$, Hatice Deniz Ilhan ${ }^{1}$, Elif Betul Turkoglu², Nalan Aydin²
}

\begin{abstract}
A 49-year-old woman with acute loss of vision in her left eye was examined in our clinic. Two months before arriving at out clinic, she was diagnosed with pancreatic endothelial carcinoma. Her visual acuities were 20/20 for the right and 20/200 for the left eye. Fundus examination and fundus fluorescein angiography showed bilateral subretinal solitary mass. Multiple metastases to lung, pleura, liver, spleen, and abdominal lymph nodes were detected during the initial diagnosis. The patient underwent chemotherapy during the period when the visual symptoms were observed. No additional treatment was offered because of the extent of the disease and poor general health. Although pancreatic endothelial carcinoma usually spreads to the abdominal visceral organs and lungs, choroidal metastases are rarely observed.
\end{abstract}

Keywords: Choroidal neoplasms/secondary; Neoplasms metastasis; Pancreatic neoplasms

\section{RESUMO}

Uma mulher de 49 anos de idade, com perda visual aguda de seu ol ho esquerdo, que teve diagnóstico de carcinoma endotelial de pâncreas há dois meses, foi examinada em nossa clínica. Suas acuidades visuais eram 20/20 no olho direito e 20/200 no olho esquerdo. O exame de fundo de olho e a angiofluoresceinografia mostraram massa solitária sub-retiniana bilateral. Múltiplas metástases do pulmão, pleura, fígado, baço e nódulos linfáticos abdominais foram detectados no diagnóstico inicial. A paciente foi submetida a quimioterapia durante o tempo que os sintomas visuais foram observados. Nenhum tratamento adicional foi oferecido por causa da extensão da doença e problemas de saúde em geral. Embora o carcinoma endotelial de pâncreas normalmente se espalhe para órgãos abdominais e pulmões, este pode ser uma causa rara de metástases de coroide.

Descritores: Neoplasias da coroide/secundário; Metástases neoplásicas; Neoplasias pancreáticas

\section{INTRODUCTION}

Uveal metastasis of carcinoma is the most common cause of ocular malignancy in adults ${ }^{(1,2)}$. Breast carcinoma and lung carcinoma cases combined account for $71-92 \%$ of the uveal metastases. Other malignancies such as prostate carcinoma and gastrointestinal carcinoma contribute only to a lesser extent ${ }^{(2)}$. A few cases of choroidal metastasis from pancreatic carcinoma have been reported ${ }^{(3-6)}$. Here we report a case of bilateral choroidal metastasis of pancreatic cancer and its clinical presentation.

\section{CASE REPORT}

A 49-year-old woman with metastases of pancreatic cancer to liver, spleen, multiple abdominal lymph nodes, and additionally with peritonitis carcinomatosa was presented to the Ophthalmology Department of the Akdeniz University Hospital with a two week history of blurred vision in her left eye two months after the diagnosis. Her best-corrected visual acuities were 20/20 for the right and 20/200 for the left eye. Intraocular pressure and external appearance were normal in both eyes. A slit-lamp examination showed no sign of intraocular inflammation. Fundus examination revealed a white-yellow dome-shaped subretinal mass of 2 optic disc diameters infero-temporal to the macula with minimal subretinal fluid on the right and a white-yellow dome-shaped subretinal mass of approximately 3 optic discs in diameters supero-temporal to the macula with shallow subretinal fluid involving juxtafoveal region (Figure 1). Pigmentary alterations at the border of both lesions were evident. Ocular USG confirmed bilateral choroidal mass, suggestive of metastasis (Figure 2). Although the lesion threatened the vision and demanded radioactive plaque brachytherapy, the medical condition of the patient deteriorated rapidly. Despite further chemotherapy, the patient died six months after the diagnosis of ocular metastasis. During the follow-up bedside exams, a subjective improvement in vision was noted and the left choroidal lesion shrunk to the diameter of one disc with no subretinal fluid. The choroidal dome-shaped mass on the right eye fully regressed and we observed retinal pigmentary changes, two discs in diameter, in place of the original lesion.

\section{DISCUSSION}

Here, we report a case of bilateral choroidal metastasis of pancreatic cancer. Pancreatic cancer ranks fourth among the cause of cancerrelated deaths in the United States ${ }^{(7)}$. Majority of the patients present a stage IV disease, with metastasis occurring mainly into the liver and peritoneal cavity ${ }^{(5)}$

Bilateral metastasis of pancreatic cancer into choroid is extremely rare. Shields et al. ${ }^{(8)}$ reported 950 cases of uveal metastases in 520 eyes of 420 consecutive patients, of which only 1 man $(<1 \%)$ had pancreatic cancer. Shah et al ${ }^{(6)}$ described a patient with bilateral choroidal metastasis. The only other bilateral case reported was in French literature ${ }^{(4)}$. The present case was only the third with bilateral choroidal metastasis.

Blurred vision is the most commonly presented symptom of uveal metastasis. Other common symptoms include photopsia, scotoma, floaters, metamorphopsia, and ocular pain ${ }^{(2)}$. The symptom of pain is rare in primary uveal malignancies. Typical choroidal metastases show one or more solitary and slightly elevated lesions with depigmentation and hyperpigmentation on the surface. Exudative detachment may or may not be present. It is not possible to know the origin of the

Submitted for publication: September 30, 2013

Accepted for publication: January 29, 2014

Study conducted at Ophthalmology Department, Akdeniz University Hospital.

Funding: This study was supported by Akdeniz University Scientific Projects Unit.

Disclosure of potential conflicts of interest: None of the authors have any potential conflicts of interest to disclose.

Akdeniz University, Faculty of Medicine, Department of Ophthalmology, Antalya, Turkey.

2 Serik State Hospital, Ophthalmology Clinic, Antalya, Turkey.

Corresponding author: Elif Betul Turkoglu. Akdeniz Universitesi Hastanesi, Goz Hastaliklari A.D., Dumlupinar Blv, 07058, Antalya, Turkey - Email: drelifbetul@yahoo.com 

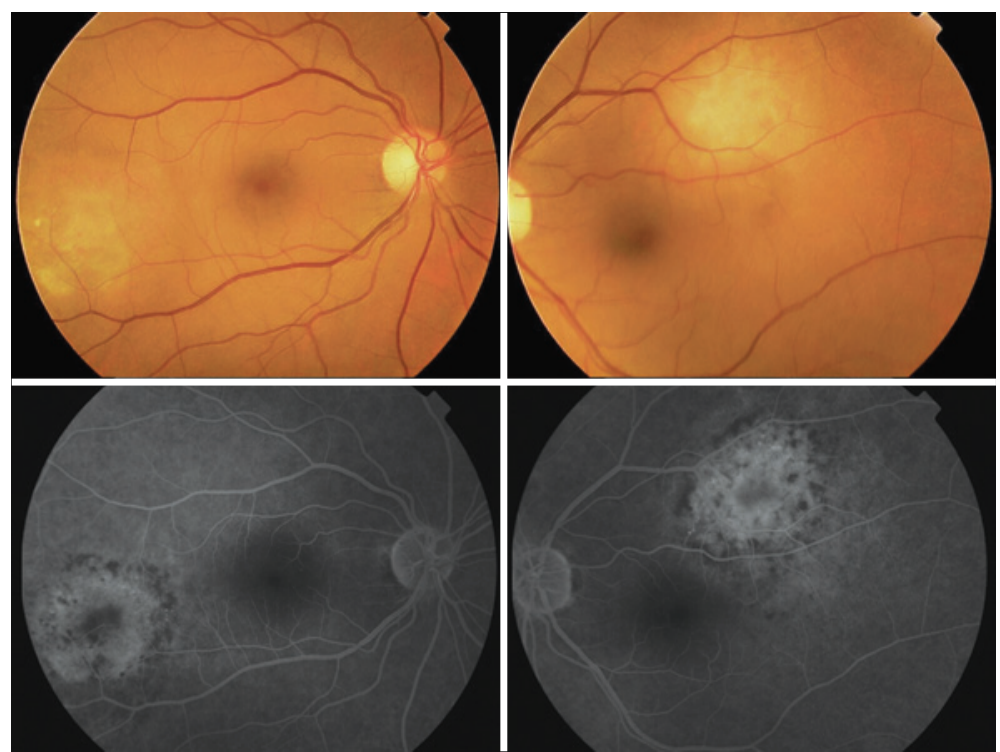

Figure 1. Fundus photography and fluorescein angiography (FA). Bilateral temporal hypopigmented lesions are observed. On the FA, the lesions appear as dotted hyperfluorescent structures.

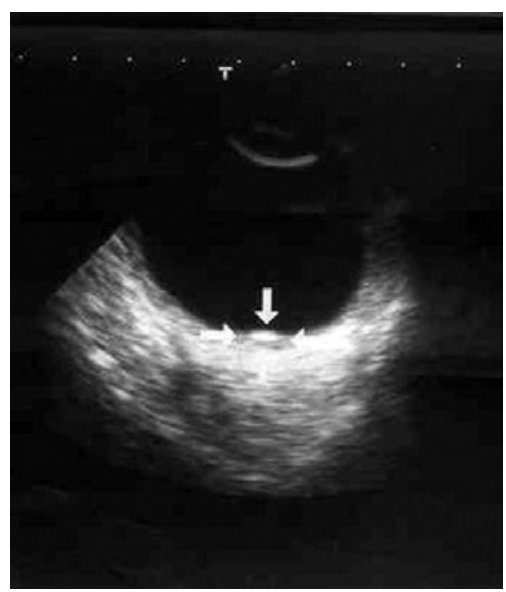

Figure 2. Ophthalmic ultrasonography. Hyperecogenic lesion (choroidal mass) on the posterior pole is seen.

lesions from fundus examination alone. Detailed abdominal and thoracal imaging should be performed when rapidly growing choroidal tumors of unknown origin are present ${ }^{(5,8)}$.

The reported cases had systemic metastasis ${ }^{(5)}$. Metastasis to multiple organs was also evident in the present case. Ocular metastasis of malignant tumors is a poor prognostic sign, with a reported life expectancy of 0.2 to 48 months $^{(2,3)}$. Ocular metastasis is treated with chemotherapy combined with brachytherapy to reduce the size of the metastatic lesion, if the lesion causes vision $\operatorname{loss}^{(9)}$. Other therapeutic options include external beam radiotherapy, photodynamic therapy, and observation (for detecting intraocular complications) ${ }^{(10,11)}$. Un- fortunately, the medical condition of our patient worsened and she could not tolerate radiotherapy for ocular metastasis. We observed that the subjective and objective improvements of the features were a result of the chemotherapy.

Several screening studies have shown that most patients with uveal metastasis are asymptomatic, and when patients become symptomatic, the symptoms generally worsen rapidly. In conclusion, bilateral uveal metastasis can be related to systemic disseminated disease and influence life expentancy. Intraocular metastatic lesions should be treated as a systemic disease.

\section{REFERENCES}

1. Bloch RS, Gartner S. The incidence of ocular metastatic carcinoma. Arch Ophthalmol. 1971;85(6):673-5.

2. Kanthan GL, Jayamohan J, Yip D, Conway RM. Management of metastatic carcinoma of the uveal tract: an evidence based analysis. Clin Experiment Ophthalmol. 2007; 35(6):553-65

3. Nasser M, Haj M, Nassar F. Carcinoma of pancreas presenting as a decrease in visual acuity. Hepatogastroenterology. 2002:49(44);558-60

4. Castillo J, Ascaso FJ, Aguelo JM, Minguez E, Cristóbal JA, Palomar A. Bilateral choroidal metastases of pancreatic carcinoma. J Fr Ophthalmol. 1995;18(12):795-8.

5. Lin CJ, Yang CM, Chen MS. Intraocular metastasis of pancreatic cancer: report of two cases. Retina. 2001;21(6):666-9.

6. Shah SU, Shields CL, Bianciotto CG, Shields JA. Pancreatic cancer metastasis to cho roid. Ophthalmology. 2011;118(7):1483-1483.e4

7. Siegel R, Ward E, Brawley O, Jemal A. Cancer statistics, 2011: the impact of eliminating socioeconomic and racial disparities onpremature cancer deaths. CA Cancer J Clin. 2011; 61(4):212-36.

8. Shields CL, Shields JA, Gross NE, Schwartz GP, Lally SE. Survey of 520 eyes with uvea metastases. Ophthalmology. 1997;104(8):1265-76.

9. Hidalgo M. Pancreatic cancer. N Engl J Med. 2010;362(17):1605-17.

10. Sinclair JC, Gold AS, Murray TG. Bilateral choroidal metastases from primary esophageal melanoma: a rare case. Optom Vis Sci. 2012;89(4):502-6.

11. Kawakami S, Wakabayashi Y, Goto H. A case of presumed choroidal metastasis from carcinoid tumor treated by photodynamic therapy with verteporfin. Clin Ophthalmol. 2013;7:2003-6. 